\title{
Studies on nucleic acid derivatives in cheese
}

\section{The changes of acid-soluble nucleotides in the surface-ripened cheese by yeast and bacteria}

\author{
Chin-Wen Lin, Umeo Yoshino and Tomokichi Tsugo \\ (Faculty of Agriculture, University of Tokyo) \\ (Received for Publication on October 22, 1968)
}

The ripening of cheese proceeds with the action of various enzymes of the inoculated or naturally occurred microorganisms in cheese. These microorganisms give a characteristic flavor to each type of cheese. Many chemical components are responsible for the flavor of cheese. Among them, amino acids, volatile sulfur compounds and carbonyl compounds are well-known as the principal flavor compounds and many works have been done with these substances ${ }^{14)}$.

Some of the nucleotides have good flavor ${ }^{\text {b) }}$, but only a few studies on their presence in cheese have so far been made. In the previous works $\mathrm{s}^{9,13)}$ the changes of acid-soluble nucleotides in Blue, Cheddar and semi-soft white mold cheeses curing their ripening were investigated and it was shown that both their amount and distribution were different in each type of cheese. And it was also found that the amount of nucleotide derivatives seemed not enough to influence the cheese flavor.

Yeast cell usually contains a larger amount of nucleic acid than bacteria or fungi cell does. In this report, the surface-ripened cheese was manufactured by yeast and Brevibacterium linens, and the possibility of the liberation of nucleic acid derivatives from yeast cells into cheese during the ripening was investigated.

\section{Methods and Materials}

1. Determination of proteolytic activity of yeast

The following strains of yeast were investigated for their proteolytic activity; Candida mycoderma IAM 4564, Candida utilis IAM 4220, Saccharomyces fragilis IAM 4763, Candida rugosa IAM Zatsu-10-3, Debaryomyces hansenii IAM Ch-1-1. One roopful of yeast cultured in a liquid medium (malt extract $5 \%$, glucose $1 \%, \mathrm{pH} 5.0$ ) was inoculated in $10 \mathrm{~m} l$ of skimmilk, and incubated at $25^{\circ} \mathrm{C}$. After 7 and 14 days' incubation, $10 \mathrm{~m} l$ of $0.4 \mathrm{M}$ trichloroacetic acid was added and by filtering off the precipitate formed the filtrate was obtained. The proteolytic activity of yeast was estimated from the tyrosine content in the filtrate. Tyrosine was measured by the Folin phenol reagent method ${ }^{11)}$.

2. Observation of cheese curd smeared with yeast

The cheese curd was made from whole milk in accordance with the method of manufacturing semi-soft white mold cheese ${ }^{(2)}$. It was cut into $5 \times 5 \times 0.5 \mathrm{~cm}$ in size, and smeared with each strain of yeast culture in the liquid medium. The smeared cheese curd was incubated in a petri dish at $25^{\circ} \mathrm{C}$ for 4 days, and then the flavor and softness of the curd were examined organoleptically.

3. Manufacture of surface-ripened cheese

Cheese was made in accordance with the mathod of Tsugo and Kato ${ }^{15}$, using Brevibacterium 
linens ATCC 9175 and yeast.

4. Analysis of cheese

Moisture, titratable acidity, $\mathrm{pH}$, total nitrogen, water soluble nitrogen, ammonia nitrogen, free tyrosine and phosphatase activity were determined by the procedures described previously ${ }^{18}$. 5. Identification of nucleotides

Twenty grams of ground cheese was extracted with $50 \mathrm{~m} l$ of chilled $10 \% \mathrm{HClO}_{4}$ for 5 minutes in a laboratory homogenizer (Nihon Seiki Kogyo, HD-type), and centrifuged for 10 minutes at $2,500 \mathrm{rpm}$. The residue was reextracted in the same manner with $50 \mathrm{~m} l$ of chilled $5 \% \mathrm{HClO}_{4}$. These extracts were combined and immediately adjusted with $5 \mathrm{~N} \mathrm{KOH}$ to $\mathrm{pH} 6.5$ in an ice-bath. After centrifuging off the precipitate of $\mathrm{KClO}_{4}$, the extract adjusted at $\mathrm{pH} 6.5$ was analysed for nucleotides. The extract was fractionated by ion exchange chromatography on a Dowex 1-X 8 column (formate form), and each fraction obtained was identified by paperchromatography and the determination of phosphorus ${ }^{17)}$, ribose ${ }^{1)}$ and bases ${ }^{9 /}$. The content of nucleotide in each fraction was estimated by using the molar absorbancy index at $260 \mathrm{~m} \mu^{16)}$. The details of the experimental procedures were similar to those given in the previous reports ${ }^{9,13)}$.

\section{Results and Discussion}

1) Selection of yeast

In the surface-ripened cheese made with yeast and bacteria, as for bacteria Brevibacterium linens was detected overwhelmingly, and yeast was also found in large numbers ${ }^{15}$. Five strains of yeast were examined for the proteolytic activity in skimmilk, and the organoleptic changes of cheese curds ripened by individual strains of yeast were observed to select suitable

Table 1. Proteolytic activity of yeast in skimmilk

\begin{tabular}{llc}
\hline \hline \multicolumn{1}{c}{ Yeast } & Increase in tyrosine content in cultured skimmilk & \multicolumn{1}{c}{$(\mathrm{mg} \%)$} \\
\hline & 7 days* & 14 days* \\
C.ndida mycoderma IAM 4564 & 5.8 & 5.9 \\
Saccharomyces fragilis IAM 4763 & 8.0 & 17.7 \\
Candida rugosa IAM Zatsu-10-3 & 5.2 & 5.6 \\
Candida utilis IAM 4220 & 6.5 & 7.5 \\
De5aryomyces hansenii IAM Ch-1-1 & 5.6 & 5.9 \\
\hline
\end{tabular}

* Incubation period

Table 2. Comparison of cheese curds smeared with various strains of yeast

\begin{tabular}{|c|c|c|c|}
\hline Yeast & Softness & Flavor & \\
\hline Candida mycoderma IAM 4564 & $+^{*}$ & $\begin{array}{l}\text { yeast flavor } \\
\text { putrid flavor }\end{array}$ & $\begin{array}{l}H^{*} \\
\pm\end{array}$ \\
\hline Saccharomyces frcgilis IAM 4763 & + & $\begin{array}{l}\text { yeast flavor } \\
\text { ammonia flavor }\end{array}$ & $\begin{array}{l}+ \\
\pm\end{array}$ \\
\hline Candida rugosa IAM Zatsu-10-3 & H & $\begin{array}{l}\text { yeast flavor } \\
\text { putrid flavor }\end{array}$ & $\begin{array}{l}+ \\
\pm\end{array}$ \\
\hline Candida utilis IAM 4220 & H & $\begin{array}{l}\text { yeast flavor } \\
\text { cheese flavor }\end{array}$ & \pm \\
\hline Dejaryomyces han:enii IAM Ch-1-1 & $H$ & $\begin{array}{l}\text { yeast flavor } \\
\text { putrid flavor }\end{array}$ & 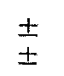 \\
\hline Control & \pm & moldy flavor & + \\
\hline
\end{tabular}

*,, \pm++ : signs for degree of softness and intensity of flavor 
strain for cheese manufacture. These results were given in Tables 1 and 2.

The proteolytic activities of test strains in skimmilk were different from each other. Generally, the stronger proteolytic activity was, the softer cheese curd was. In addition to the proteolytic activity, the ammonia flavor of cheese curd should be taken into consideration. The intensity of ammonia flavor was not always consistent with the proteolytic activity and the softness of curd. As shown in Tables 1 and 2, Saccharomyces fragilis in skimmilk showed remarkably strong proteolytic activity, while ammonia flavor of cheese curd treated with this strain was relatively weak. But in cheese making, since it is particularly desirable that the intensity of ammonia flavor would be as weak as possible, according to the results in Tables 1 and 2, Candida utilis was selected as the most suitable strain for cheese making.

2) Manufacture of cheese

The cheese was made by the method of Tsugo and KaTo for manufacturing surface-ripened chees ${ }^{15)}$. It was ripened at $15^{\circ} \mathrm{C}$, under $80-90 \%$ relative humidity in the ripening room. During the ripening period, the experimental samples were taken periodically. The changes of chemical composition of cheese during the ripening were given in Table 3. The results showed that the ripening of the cheese seemed to have proceeded normally. Judging from the flavor of cheese, the most suitable ripening period was 28 days, which was week longer than that of the semi-soft white mold cheese ${ }^{12)}$.

Table 3. The changes of chemical composition of the surface-ripened cheese during ripening

\begin{tabular}{|c|c|c|c|c|c|c|c|c|}
\hline \multicolumn{3}{|c|}{ Period of ripening (days) } & 0 & 7 & 14 & 21 & 28 & 42 \\
\hline Moisture & $(\%)$ & & 48.28 & 41.48 & 43.03 & 42.86 & 41.19 & 38.21 \\
\hline Acidity* & $(\%)$ & & 2.16 & 2.71 & 2.16 & 1.80 & 1.62 & 1.44 \\
\hline Protein & $(\%)$ & & 20.54 & 22.52 & 23.10 & 24.18 & 25.26 & 24.95 \\
\hline $\mathrm{pH}$ & & & 5.18 & 4.80 & 5.38 & 5.68 & 6.08 & 6.20 \\
\hline Total nitr & & $(\%)$ & 3.28 & 3.53 & 3.62 & 3.79 & 3.96 & 3.91 \\
\hline Water sol & rogen & $(\%)$ & 0.26 & 0.35 & 0.61 & 0.93 & 1.22 & 1.64 \\
\hline Ammonia & & $(\%)$ & 0.04 & 0.04 & 0.05 & 0.09 & 0.10 & 0.19 \\
\hline Tyrosine & & $(\mathrm{mg} \%)$ & 36.0 & 39.0 & 90.0 & 142.6 & 197.5 & 355.0 \\
\hline Ripening & & $(\%)$ & 7.93 & 9.92 & 16.85 & 24.53 & 30.81 & 41.94 \\
\hline
\end{tabular}

* Calculated as lactic acid percent

** Ripening ratio: water soluble nitrogen/total nitrogen $\times 100$

After 10 days' ripening, characteristic pink color appeared on the surface of cheese, which, as the ripening proceeded, gradually turned red. The ripening proceeded a little slower than in the case of the semi-soft white mold cheese ${ }^{12)}$, where ripening ratio increased rapidly after 14 days' ripening.

3) Identification of nucleotides

The concentrated extract of nucleotides from $20 \mathrm{~g}$. of cheese ripened for 28 days was applied to a Dowex 1-X 8 column (formate form). The column was washed with distilled water, and eluted with the mixture of formic acid and sodium formate, the concentrations of which were increased stepwisely as shown in Fig. 1. The eluted fractions from the column, as shown in Fig. 1, were identified as follows: I. 5'-AMP (5'-adenosine monophosphate), II. 5'IMP (5'-inosine monophosphate), III. GTP (guanosine triphosphate), IV. ADP (adenosine diphosphate), V. ATP (adenosine triphosphate) and VI. GMP (guanosine monophosphate). 
Acid-soluble nucleic acid derivatives in cheese

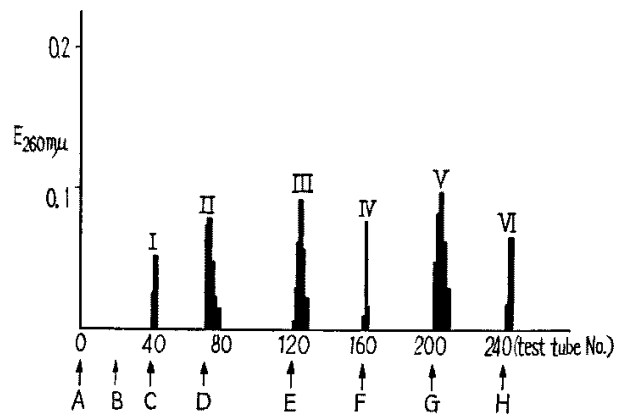

Fig. 1. Elution pattern of nucleotides in the surface-ripened cheese $(20 \mathrm{~g})$ ripened for 28 days on the column chromatography.

The column chromatography was carried out using a column $(1.0 \times 10 \mathrm{~cm})$ containing an anion exchange resein Dowex 1-X 8 (200-400 mesh) formate form. Flow rate was $1.5 \mathrm{~m} l$ per minute. Each $10 \mathrm{~m} l$ fraction was collected in a tube.

Elution solutions were as follows: $A, 0.005 \mathrm{M}$ formic acid (FA), B, 0.02 M FA. C, 0.IM FA. D, 0.1 M FA+0.1 sodium formate (FNa). E, 0.1 MFA+0.6 M FNa. F, $0.1 \mathrm{M} \mathrm{FA}+0.8 \mathrm{M}$ FNa. G, 0.5M FA+1.0M FNa. H, 2.0M FA+1.0M FNa

I, 5'-AMP; II, 5'-IMP; III, GTP; IV, ADP; V. ATP; VI, GMP

There are four isomers of GMP, that is, $2^{\prime}-, 3^{\prime}-, 5^{\prime}-$ and cyclic GMP. In this study however, the location of the phosphate group on the ribose ring was not investigated.

4) The changes of content of nucleotides

In the process of cheese ripening, as the physical, chemical and microbiological changes take place all the time, the content of nucleotides in the cheese may also vary. Table 4 shows the changes of the content of nucleotides ( $\mu \mathrm{M}$ per $100 \mathrm{~g}$ of cheese). As shown in Table 4 , the total content of nucleotides increased gradually during the ripening. After 28 days' ripening, the total content of nucleotides reached a maximun of $9.8 \mu \mathrm{M}$, increasing linearly from the beginning day of ripening, and thereafter decreased again in over-ripened cheese (42-days' ripening). The decrease of the total content of nucleotides may presumably be caused by the action of phosphatase. Namely, as the phosphatase activity was found to be $0,0.62$, 1.31 and 1.94 unit $^{2)}$, at $7,14,28$ and 42 days' ripening, respectively, it may be explained that the decrease of the total content of nucleotides in the over-ripened cheese, as shown in Fig. 2, was due to the increased phosphatase activity.

Table 4. The changes of contents of nucleotides in the surface-ripened cheese during ripening

\begin{tabular}{|c|c|c|c|c|c|c|}
\hline & & \multicolumn{5}{|c|}{ Period of ripening (days) } \\
\hline \multicolumn{2}{|c|}{ Fraction nucleotide } & 0 & 7 & 14 & 28 & 42 \\
\hline & & \multicolumn{5}{|c|}{$\mu \mathrm{M} / 100 \mathrm{~g}$} \\
\hline I & $5^{\prime}-\mathrm{AMP}$ & & 0.1 & 0.3 & 0.6 & 0.6 \\
\hline II & $5^{\prime}-\mathrm{IMP}$ & & & 1.1 & 2.5 & 2.3 \\
\hline III & GTP & 0.7 & 0.8 & 1.6 & 2.7 & 1.8 \\
\hline IV & $\mathrm{ADP}$ & & 0.3 & 0.4 & 0.4 & 0.4 \\
\hline $\mathrm{V}$ & ATP & 0.8 & 0.9 & 2.4 & 2.4 & 0.8 \\
\hline V] & GMP & 3.2 & 3.5 & 1.2 & 1.2 & 1.3 \\
\hline \multicolumn{2}{|c|}{ Total } & 4.7 & 5.6 & 7.0 & 9.8 & 7.2 \\
\hline
\end{tabular}




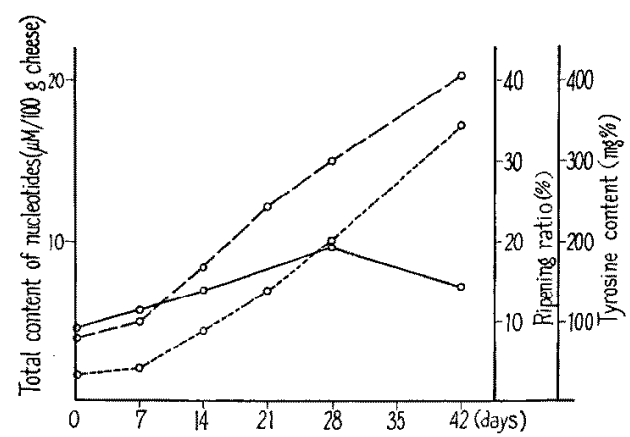

Fig. 2. The relations of total content of nucleotides to ripening ratio and tyrosine content of cheese

$$
\begin{aligned}
\text { Curves } & -\mathrm{O}-\mathrm{O}-\text { total content of nucleotides } \\
& \cdots-\mathrm{O}-\mathrm{O}-\text { ripening ratio } \\
\cdots & \cdots \cdots \cdots \text { tyrosine content }
\end{aligned}
$$

The nucleotides in the eluted fractions were identified as shown in Table 4. All of them. belonged to the purine base compounds, and the adenine derivatives occupied most part of them. In these derivatives, the following sequence of enzymatic reactions has been found in fish meat during the storage ${ }^{5)}: \mathrm{ATP} \longrightarrow \mathrm{ADP} \longrightarrow \mathrm{AMP} \longrightarrow \mathrm{IMP} \longrightarrow$ inosine. This pathway, however, was not found in this study. This may possibly be due to the fact that the autolysis. and metabolic activities of microorganisms had conceivably proceeded simultaneously.

Two nucleotides of $5^{\prime}$-IMP and $5^{\prime}-$ GMP have been shown to have marked flavor-enhancing properties $^{7}$. Both of them were detected in this cheese only in small quantities (Table 4). The effectiveness of these flavor enhancers depends on the nature of food in which they are present. It is, therefore, difficult to say whether their amount appeared in this cheese is sufficient to affect the cheese flavor.

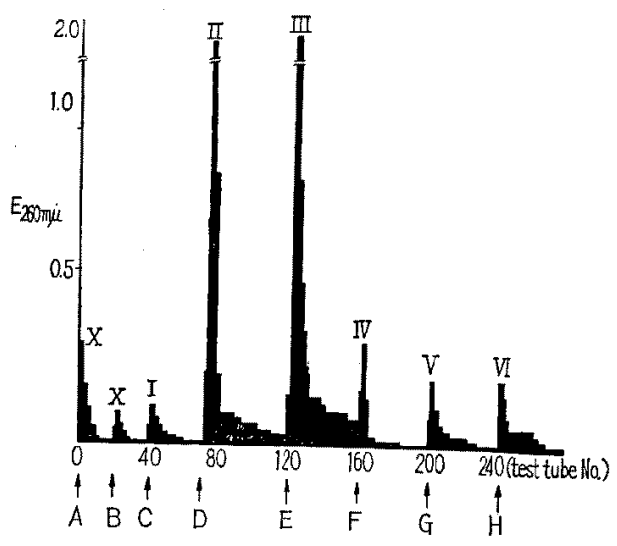

Fig. 3. Elution pattern of nucleotides extracted from yeast cells $(5 \mathrm{~g})$ on column chromatography

The conditions of column chromatography were the same as given in Fig 1 . I, 5'-AMP; II, 5'-IMP; III, GTP; IV, ADP; V, ATP; VI, GMP.

To make sure the origin of nucleotides in this cheese, the yeast used was examined. The yeast cell is known to contain a great amount of RNA and free nucleotides. It might be considered that the appearance of nucleotides in this cheese resulted from the hydrolysis of RNA by ribonucleotidase, or that they were released from the living yeast cell. 
Acid-soluble nucleic acid derivatives in cheese

If the released nucleotides originated from the hydrolysis of RNA, purine and pyrimidine bases of nucleotides should be detected equally in cheese extract. In addition, the action of ribonucleotidase on RNA would yield nucleotide $-3^{\prime}$ or $-2^{\prime}$ monophosphate ${ }^{4}$. But, in this cheese, the quantities of porine and pirimidine bases were not equal and nucleotide $-3^{\prime}$ or $-2^{\prime}$ monophosphate was not detected (Table 4). So, there seems no possibility that nucleotides were derived from RNA in yeast cells.

Whether the leaked nucleotides from the free pool in yeast cells could be the origin of nucleotides in cheese was studied. The used yeast, Candida utilis, was cultured in the medium of Szumski-Cone $e^{10)}$ at $26.5^{\circ} \mathrm{C}$ for 4 days. The cells were collected by centrifugation, washed with $0.85 \%$ saline several times, and freeze-dried. The dry yeast cells were extracted with water by grinding with sea sand. The extract was analysed for nucleotides, the results being shown in Fig. 3. The elution pattern was qualitatively almost similar to that of the cheese extract, which suggested the leakage of nucleotides from yeast cells into cheese.

Delisle and haff $^{31}$ showed that the UV-absorbing fraction was released from viable healthy yeast cells. Lee and Lewis ${ }^{8}$ showed that the extent of release was dependent on the $\mathrm{pH}$, temperature and concentration of fermented sugars of medium and on the presence of the membrane-damaging or protecting reagents.

Considering $\mathrm{pH}$ and temperature conditions, any significant amount of nucleotides could hardly be expected to have been released from free pool of cells in the circumstance of cheese

Table 5. The content of nucleotides in the outer and inner zones of surface-ripened cheese

\begin{tabular}{ccccc}
\hline Portion of cheese & $\begin{array}{c}\text { Period of ripening } \\
\text { (days) }\end{array}$ & $\begin{array}{c}\text { Absorbance } \\
\text { at } 260 \mathrm{~m} \mu \\
\text { (per } 100 \mathrm{~g})\end{array}$ & $\begin{array}{c}\text { Content of } \\
\text { nucleotides } \\
\text { calculated } \\
\text { as AMP }(\mu \mathrm{M})\end{array}$ & $\begin{array}{c}\text { Dry matter } \\
(\%)\end{array}$ \\
\hline Outer zone & 14 & 121.95 & 8.57 & 59.94 \\
Inner zone & 28 & 133.50 & 9.35 & 58.85 \\
& 14 & 100.55 & 7.06 & 62.35 \\
\hline
\end{tabular}

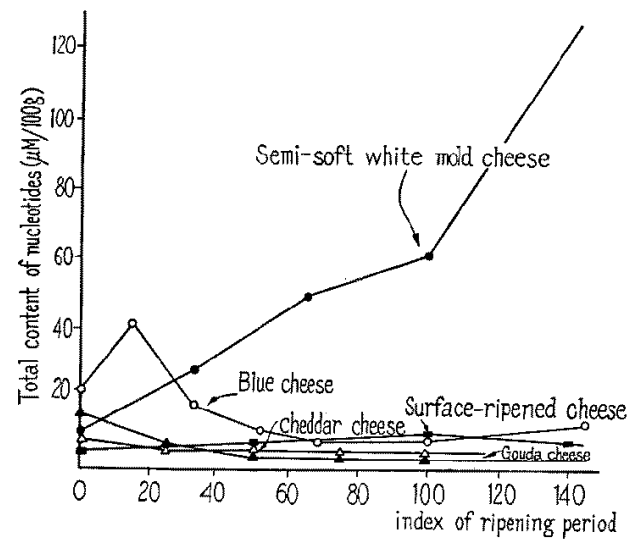

Fig. 4. The changes of total content of nucleotides during ripening in the various types of cheeses

*Index of ripening period $=\frac{\text { period of ripening }}{\text { period of optimum ripening }} \times 100$ 
ripening. For elucidating this, the cheese was cut into three zones; the outer, middle and inner zones, and the nucleotides in the outer and inner zones were analyzed (Table 5). In spite of the growing of yeast in outer zone, the content of nucleotides in outer zone was only slighly higher than that in inner zone, indicating that the pressnce of yeast had not much effect on the quantities of nucleotides in this cheese.

In the previous reports ${ }^{9}, 18$, the nucleotides in various cheeses, such as Gouda, Cheddar, Blue and semi-soft white mold cheeses were investigated. For comparison of the changes of the total nucleotide content in these cheeses, the total nucleotide content was plotted against the index of ripening period (period of ripening/period of optimum ripening $\times 100$ ) in Fig. 4 . The results showed that, at the time of optimum ripening (the index 100), the total nucleotide content in surface-ripened cheese by yeast and Brevibacterium linens was similar to that of Blue cheese, and was a little higher, as compared with Gouda and Cheddar cheeses.

\section{Summary}

The changes of the acid-soluble nucleic acid derivatives were studied during the ripening of cheese manufactured by using Candid $x$ utilis and Brevibacterium linens. The nucleotides in cheese extracts were analysed by chromatography with Dowex $1-\mathrm{X} 8$ column, and identified as 5'-IMP, 5'-AMP, GTP, ADP, ATP and GMP.

These nucleotides were considered to have originated not from RNA but from free pool of nucleotides in yeast cells. Their amount in cheese at the time of optimum ripening $(9.8 \mu \mathrm{M}$ per $100 \mathrm{~g}$ cheese) was similar to that of Blue cheese and a little larger than that of Gouda and Cheddar cheeses, and did not seem enough to aflect cheese flavor.

\section{Acknowledgement}

Authors wish to express their thanks to Dr. H. IIzUKa who kindly supplied us yeasts and Brevi:acterium linens, and to Dr. $\mathrm{K}$. TANIGUCHI for his advices throughout this work.

\section{References}

1) Albaum H.G. and W.W. Umbreit (1947) J. Biol. Chem., 167: 369-376.

2) Bessy, O.A., O.H. Lowry and J. M. Broch (1946) J. Biol. Chem., 164: 321-329.

3) Delisle, A.L. and H.J. Phaff (1961) Brewer's Digest 1961: 35-39.

4) Higuchi, M. and T. Uemura (1959) Nature, 184: 1381-1383.

5) Kassemsarn, B., B.S. Perez, J. Murray and N.R. Jones (1963) J. Food Sci., 28: 28.

6) Kuninaka, A. (1960) J. Agric. Chem. Soc. Jap., 34: 489-492.

7) Kuninaka, A., M. Kibi and K. Sakaguchi (1964) Food Technol., 18: 287-294.

8) LeE, T.C, and M.J. Lewis (1968) J. Food, Sci., 33: 124-127.

9) Lin, C.W., K. Taniguchi and T. Tsugo (1968) Jap. J. Zootech, Sci., 39: 446-455.

10) Szumski, S.A. and J.F. Cone (1962) J. Dairy Sci., 45: 349.

11) Tokyodaigaku Nogeikagaku Kyoshitsu (1962) Zikken-Nogeikagaku, Vol. I p. 281.

12) Tsugo, T. and H. Matsuoka (1964) Jap. J. Zootech. Sci., 29: 345-349.

13) Tsugo, T., K. Taniguchi and C.W. Lin (1967) Jap. J. Zootech. Sci., 38: 18-23.

14) Tsugo, T. and M. Iwaida (1966) J. Ferment. Assoc. Japan., 24: 495-504.

15) Tsugo, T. and Y. Kato (1964) Jap. J. Zootech. Sci., 35: 197-203.

16) Volkin, E. and W.E. CoHn (1964) Methods of Biochemical Analysis, Interscience Publishers. Inc. New York, 1: 287.

17) Weli-Malherbe, H. and R.H. Green (1951) Biochem. J., 49: 286-292. 


\section{チーズ中の核酸関連物質に関する研究}

III. 酵母および細菌による表面熟成チーズにおける酸可溶性核酸関連物質の変化

\section{林慶文・吉野梅夫・津郷友吉}

(東京大学農学部)

Brevibacterium linens および Candida utilis 安用い た表面熟成チーズの熟成中における酸可溶性核酸閔運物 質の変化を調べた，チーズ中のヌタレオチドを陰イオン 交換樹脂 (Dowex 1-X 8, ぎ酸型; メッシニ 200〜400) 它用いたカラムクロマトグラフィーにより分別定墨し， 各区分它同定した、その結果，この種のチーズに存す るヌクレオチドは 5'-IMP, 5'-AMP, GTP, ADP, ATP
およびGMPの6 種であった。また通度の熟成状態での こ机物質の全含有量 $(100 \mathrm{~g}$ 当り $9.8 \mu \mathrm{M})$ はブルーチ ーズと同じ程度でゴーダおよびチェダーチーズよりや や多かった，これら物質は直接チーズの風沬に影望はな いと考えられる。チーズのこれらのヌクレオチド類は醉 母の菌体内遊踏ヌクレオチド類が囷の死後その自己分解 によって出現したむのと推定された。 